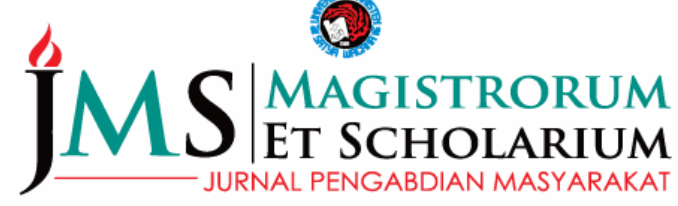

P-ISSN: 2722-9270 ejournal.uksw.edu/jms

\section{Pendampingan Pembelajaran Daring Parsial dan Terpadu Berbasis 3CM (Cool-Critical-Creative-Meaningful) Learning untuk Mengatasi Kejenuhan Belajar dan Kreativitas Implikasi Dampak Covid-19}

\author{
Wahyudi \\ Tri Nova H. Yunianta \\ Erlina Prihatnani \\ Kristina Roseven Nababan* \\ Dani Kusuma \\ Anisa Rizki Amalia \\ Bella Ayu Permatasari \\ Cindy Aprillya Sidarta \\ Bagas Prima Kristanto \\ Syera Trivena Dessiane \\ Erlin Prasetyo
}

Fakultas Keguruan dan IImu Pendidikan, Univeritas Kristen Satya Wacana

\section{A R T I C L E I N F O}

\section{Article history:}

Received 26 Agustus 2021

Revised 10 September 2021

Accepted 24 Oktober 2021

Key words:

Mentoring, Partial Online, Integrated Online, 3CM Model, Saturation, Creativity, Impact of Covid-19

\section{A B S T R A C T}

The Covid-19 pandemic has a huge impact on aspects of human life, one of which is in the world of education. Schools, teachers, learners and parents were also affected. The learning process that should be able to be performed in school with the assistance of teachers directly, now must move home by online with parental assistance. Accordance with the policy of the Ministry of Education and Culture of the Republic of Indonesia, namely Learning From Home by online. This sudden change in the way of learning makes it difficult for teachers to prepare and carry out learning. Ordinary learning is still difficult to do moreover learning that demands the creativity of teachers and learners. The ability of teachers to utilize technology is not good enough, so it becomes difficult if they have to do online learning. From the results of the survey, almost all learning activities are performed by sending materials and assignments, then tasks are done by students and the results are sent through WhatsApp groups (89.7\% of 271 respondents). Learners become saturated and want to return to study in school $(72.12 \%)$ which has an impact on decreasing opportunities to do creative activities for learners. The solution of this problem is to provide online learning facilities and support for teachers in preparing learning as well as for students and parents during the learning process. This will help teachers in preparing online learning so that teachers have enough time to develop materials and

\footnotetext{
*Corresponding author. kristina.nababan@uksw.edu
} 
media that can be uploaded in online classes. In addition, there will be standards for organizing online classes so as to give students the opportunity to learn well, fun and can return creatively. One of the online learning designs that teachers can use is the design of online learning based on 3CM (Cool-Critical-Creative-Meaningful) learning. This learning provides students with the opportunity to develop critical, creative, meaningful thinking skills in fun and challenging ways in both partial and integrated online. The product of this activity is: 1) partial and integrated online classes; 2) Scientific articles that can be published in Community service journals.

\section{A B S T R A K}

Pandemi Covid-19 memberikan dampak sangat besar dalam aspek kehidupan manusia, salah satunya adalah dalam dunia pendidikan. Sekolah, guru, peserta didik dan orang tua turut terkena dampaknya. Proses belajar yang harusnya dapat dilakukan di sekolah dengan pendampingan guru secara langsung, sekarang harus berpindah ke rumah dengan cara daring dengan pendampingan orang tua. Hal ini sesuai dengann kebijakan Kemendikbud RI yaitu Belajar Dari Rumah (BDR) dengan cara daring. Perubahan cara belajar yang sangat tiba-tiba ini membuat guru mengalami kesulitan dalam mempersiapkan maupun melaksanakan pembelajaran. Pembelajaran yang biasa saja masih sulit dilakukan apalagi pembelajaran yang menuntut kreativitas guru dan peserta didik. Kemampuan guru memanfaatkan teknologi belum cukup baik, sehingga menjadi hal yang sulit jika mereka harus melakukan pembelajaran secara daring. Dari hasil survey, hampir seluruh kegiatan belajar dilakukan dengan mengirimkan materi dan tugas, kemudian tugas dikerjakan oleh siswa dan hasilnya dikirim lewat group WhatsApp (89,7\% dari 271 responden). Peserta didik menjadi jenuh dan ingin kembali belajar di sekolah (72,12\%) yang berdampak pada penurunan kesempatan melakukan kegiatan yang kreatif bagi peserta didik. Penyelesaian masalah atas masalah ini adalah dengan menyediakan fasilitas pembelajaran daring dan pemdampingan bagi guru dalam menyiapkan pembelajaran serta bagi siswa dan orang tua pada saat proses pembelajaran. Hal ini akan membantu guru dalam menyiapkan pembelajaran daring sehingga guru mempunyai waktu yang cukup untuk mengembangkan materi dan media yang dapat di upload di kelas daring. Selain itu akan ada standar penyelenggaraan kelas daring sehingga memberi kesempatan kepada peserta didik kembali belajar dengan baik, menyenangkan dan bisa kembali kreatif. Salah satu disain pembelajaran daring yang dapat dimanfaat guru adalah disain pembelajaran daring berbasis 3CM (Cool-Critical-Creative-Meaningful) learning. Pembelajaran ini memberikan kesempatan peserta didik mengembangkan kemampuan berpikir kritis, kreatif, bermakna dengan cara-cara yang menyenangkan dan menantang baik dalam bentuk daring parsial maupun terpadu. Luaran dari kegiatan ini adalah: 1) kelas daring parsial dan terpadu; 2) artikel ilmiah yang dapat dimuat di jurnal Pengabdian Kepada Masyarakat. 


\section{PENDAHULUAN}

Dampak Covid-19 sangat dirasakan oleh masyarakat, termasuk dalam dunia pendidikan. Hal ini menjadi salah satu penghambat terbentuknya pribadi yang kreatif untuk peserta didik. Dimana salah satu tujuan pendidikan Indonesia adalah mengembangkan potensi peserta didik menjadi manusia yang kreatif (Undang-undang Nomor 20 Tahun 2003 tentang Sistem Pendidikan Nasional, 2003). Bahkan hal ini menjadi salah satu alasan perubahan kurikulum nasional dari KTSP menjadi kurikulum 2013. Kreativitas merupakan salah satu komponen utama pendidikan abad ke-21 dan kurikulum kontemporer (Mann, 2006; Navarrete, 2013; Sternberg, 2006, 2012; Tindowen et al., 2017; Vale \& Barbosa, 2015). Kreatif menumbuhkan kreativitas yang mengarah pada pemerolehan wawasan baru, pendekatan baru, perspektif baru, atau cara baru. Daya kreativitas peserta didik menjadi sesuatu yang penting (Kadir et al., 2016; Leikin, 2013; Nuha et al., 2018) dan perlu ditumbuhkembangkan. Peluang mengembangkan kreativitas lebih besar dari pada meningkatkan kecerdasan seseorang (Dyer et al., 2011).

Pembelajaran biasa atau sering disebut dengan luar jaringan (luring) untuk mencapai tujuan tersebut masih mengalami kendala, apalagi dilakukan secara daring. Hal ini juga dirasakan oleh Yayasan Lembaga Perencanaan dan Pembinaan Pendidikan Sinode Gereja Kristen Jawa Indonesia (Yayasan LP3S). Yayasan ini beralamat di Jl. Soekarno - Hatta No. 10, Salatiga. Yayasan ini melayani sekolah-sekolah Kristen di bawah GKJ dan GKI daerah Jawa dan DIY. Proses pembelajaran di masa pandemi Covid-19 menjadi masalah dan tantangan tersendiri bagi sekolah di bawah layanan LP3S. Hasil survei terhadap 271 guru Kristen di bawah layanan LP3S didapatkan bahwa proses pelaksanaan pembelajaran dilakukan daring secara penuh sebesar 52,4\% dan blended learning 45,4\% dan sisa dengan mode lainnya.

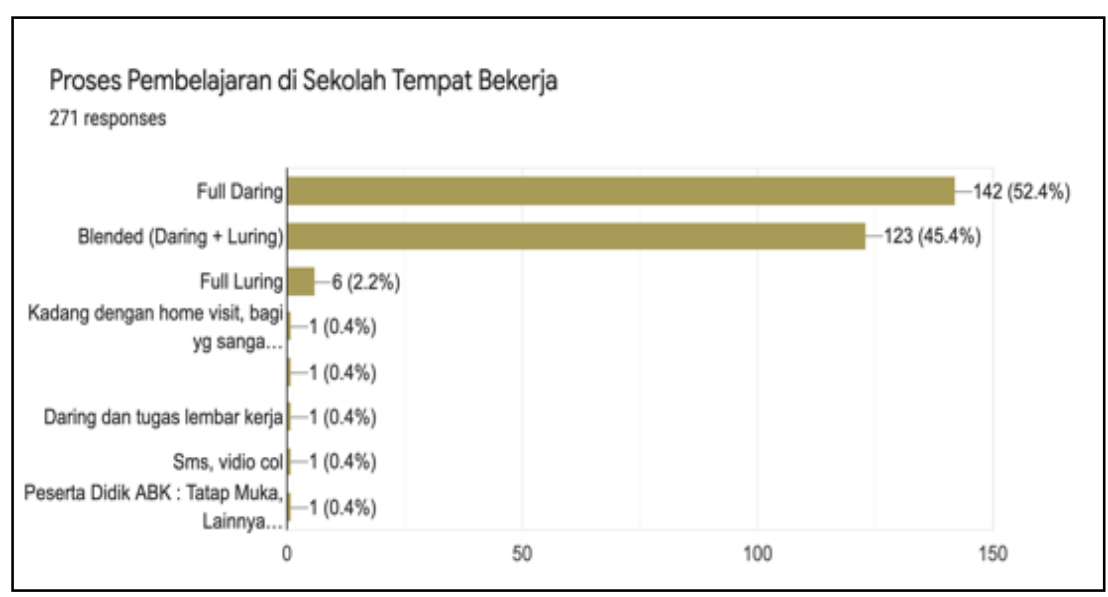

\section{Gambar 1. Mode Pembelajaran Selama Pandemi Covid-19}

Setelah dilakukan identifikasi lebih lanjut didapatkan bahwa konsep pembelajaran daring yang digunakan belum sesuai dengan konsep pembelajaran daring yang seharusnya. Data yang didapatkan adalah 89,7\% dari 271 hanya 
menggunakan fasilitas WhatsApps Group untuk memberikan materi dan mengirimkan tugas tanpa aturan yang jelas seperti yang diharuskan dalam pembelajaran daring.

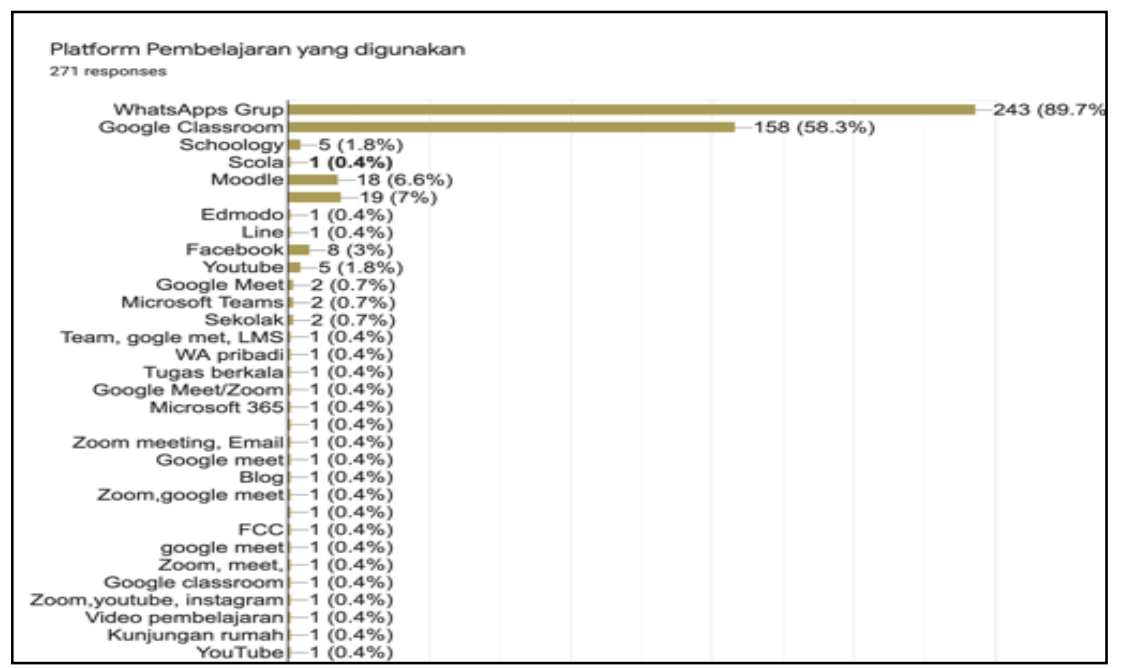

Gambar 2. Mode Pembelajaran Selama Pandemi Covid-19

Hal ini pasti memberikan dampak yang berbeda dari pembelajaran daring yang seharusnya. Hasil survey didapatkan sebagian besar peserta didik merasa bosan karena mengalami kesulitan belajar, karena tidak semua mendapat pendampingan dari orang tua. Hal ini dapat dilihat dari hasil survey yang dilakukan kepada siswa mengenai persepsi siswa dalam pembelajaran daring cukup beragam seperti membosankan, partisipasi diatas 50\%, tidak mengikuti proses pembelajaran dikarenakan sinyal, kurangnya dukungan orang tua dan bahkan ada yang menyebutkan terlalu banyak tugas yang mengakibatkan kejenuhan siswa. Materi yang diberikan sulit dipahami karena hanya materi dari buku yang dibuat dalam elektronik sehingga tidak sesuai dengan kebutuhan pembelajaran daring yang baik. Banyaknya tugas yang membuat peserta didik semakin bosan dan kurang semangat dalam belajar.

Selain itu banyak orang tua yang mengeluh karena tidak bisa mendampingi anaknya dengan baik, karena kendala materi dan juga fasilitas yang ada di rumah. Hal ini dapat dilihat dari hasil survey yang dilakukan kepada orang tua mengenai persepsi orang tua terhadap pembelajaran yang dilakukan cukup beragam seperti pembelajaran dianggap mempersulit orang tua, membuat orang tua mengeluh, pembelajaran kurang efektif, anak malas membaca dan jenuh dan juga keberatan akan pulsa/kuota internet. Sehingga menurut orang tua pembelajaran menjadi tidak efektif dan menyusahkan orang tua.

Berdasarkan permasalah yang dihadapi maka LP3S memberikan fasilitas untuk bertemu bersama dengan kepala sekolah untuk merencanakan penyelesaian masalah terkait pembelajaran daring. Solusi terhadap masalah tersebut adalah pendampingan terhadap pengembangan dan pelaksanaan kelas daring di sekolah kristen di bawah layanan LP3S. Hal ini sesuai dengan hasil survey tentang persepsi dan harapan guru terhadap pembelajaran daring yang sudah dilaksanakan dimana guru beranggapan pembelajaran yang dilakukan membebani guru, kurang efektif dalam pelaksanaan proses pembelajaran, banyaknya guru yang masih belum menguasai IPTEK, siswa 
kehilangan ketertarikan dalam belajar sehingga guru harus menghubungi siswa satu persatu. Oleh karena itu, Kepala sekolah berharap ada pendampingan untuk sekolah, guru, peserta didik, dan orang tua, baik pembelajaran daring parsial maupun daring terpadu sesuai kebutuhan setiap sekolah, guru, peserta didik, dan orang tua. Hal ini dilakukan karena belum ada standar baku terhadap kelas daring yang harus digunakan di sekolah. Setiap guru menyelenggarakan kelas daring hanya menurut pemahaman mereka bahkan hanya menggunakan group WA. Selain itu belum banyak dilakukan pendampingan pelaksanaan pembelajaran daring dengan standar baku sehingga pembelajaran berjalan dengan baik dan efektif. Dengan demikian guru dapat menjalankan tugasnya dengan baik, peserta didik dapat belajar dengan senang, Kembali kreatif, dan orang tua tidak terbebani dalam mendampingi peserta didik belajar di rumah.

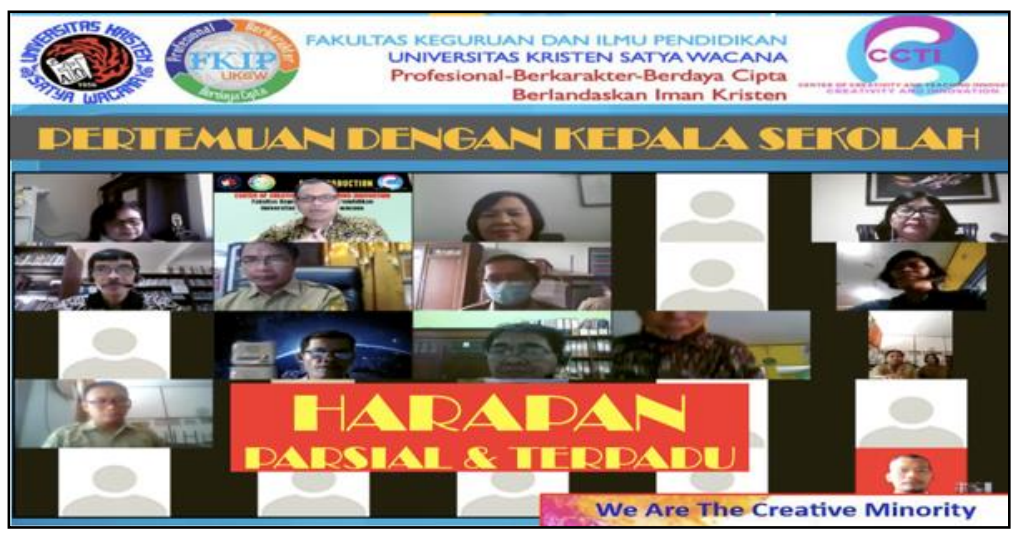

Gambar 3. Koordinasi LP3S, FKIP UKSW dan Kepala Sekolah

Luaran dari kegiatan PkM ini berupa produk siap guna berupa Kelas Daring Parsial dan Terpadu berbasis LMS Moodle dengan basis 3CM Learning dengan panduan penggunaannya. Selain itu kegiatan ini juga akan menghasilkan artikel ilmiah publish di jurnal pengabdian masyarakat hasil dari kegiatan yang telah dilaksanakan.

\section{METODE PELAKSANAAN}

Kegiatan pengabdian kepada masyarakat dilaksanakan melalui webinar menggunakan aplikasi zoom. Hal ini dikarenakan pandemi Covid-19 yang mengharuskan social distancing dan melakukan pendampingan secara virtual. Metode pelaksanaan untuk mencapai tujuan dilakukan dalam beberapa tahapan kegiatan yaituanalisis kebutuhan; workshop pembelajaran daring; pengembangan kelas daring parsial dan terpadu; pendampingan implementasi kelas daring.

Partisipasi mitra dalam pelaksanaan Program Kemitraan Masyarakat antara lain: ikut berpartisipasi dalam perencanaan kegiatan pendampingan antara lain membuat kesepakatan waktu untuk jadwal dan pelaksanaan webinar serta berperan aktif dalam pelaksanaan kegiatan.

Metode Pelaksanaan Kegiatan berdasarkan permasalahan yang dihadapi oleh mitra pengabdian, maka solusi yang ditawarkan adalah pendekatan partisipatif dalam 
bentuk kegiatan workshop pembelajaran daring, pengembangan kelas daring parsial dan terpadu hingga pendampingan implementasi kelas daring. Kegiatan pengabdian ini dilaksanakan dengan tahapan sebagai berikut:

1. Pemberian Informasi

Pemberian informasi kepada pihak mitra, guru dan orang tua dengan cara:

a. Tim Pelaksana berkomunikasi dengan mitra pengabdian yaitu sekolahsekolah dibawah naungan LP3S dengan melakukan analisis kebutuhan.

b. Membuat kesepakatan jadwal dengan pihak mitra.

c. Tim memberikan informasi tentang perlunya pemahaman etika berdemokrasi dan berpikir kritis dalam menyampaikan aspirasi.

2. Pengembangan Media Pembelajaran

Webinar yaitu workshop yang dilakukan dengan mengajak peserta untuk memberikan pemahaman berkaitan dengan pembelajaran daring dan memberikan solusi atas pembelajaran daring inovatif berbasis $3 \mathrm{CM}$ learning yang sebenarnya dengan maksud untuk memperoleh sebuah pengalaman dan pengetahuan baru bagi peserta kegiatan. Sehingga dapat dikatakan melalui pendampingan terjadi sharing informasi dari pemateri kepada para peserta. Hal tersebut merupakan satu interaksi yang terus menerus dalam satu kegiatan hingga terjadinya proses perubahan kreatif yang diprakarsai oleh peserta. Kegiatan webinar ini dilakukan dalam lima kali pertemuan yang diuraikan sebagai berikut:

a. Pertemuan pertama dilakukan oleh tim pelaksana sebagai pendamping mitra membantu sekolah menganalisis permasalahan yang ditemukan dalam proses pembelajaran dampak Covid-19 serta menemukan solusi untuk mengatasi permasalahan tersebut. Hasil analisis permasalahan tersebut akan dituangkan ke dalam latar belakang penulisan program kemitraan masyarakat sampai dengan metode pelaksanaan sebagai cara mengatasi permasalahan yang dihadapi oleh mitra pengabdian.

b. Pertemuan kedua dilakukan berdasarkan hasil pelaksanaan tindakan dalam menganalisis permasalahan mitra. Workshop yang dilakukan adalah workshop paparan materi pembelajaran daring inovatif berbasis 3CM learning. Dalam kegiatan ini ada partisipasi mitra dalam pelaksanaan program, baik melalui partisipasi aktif dalam setiap kegiatan. Analisis kebutuhan dan workshop pembelajaran daring sudah dilakukan karena kegiatan ini merupakan kegiatan lanjutan dari kegiatan PkM sebelumnya.

c. Pertemuan ketiga dilakukan pendampingan dalam pengembangan pembelajaran daring inovatif berbasis 3CM learning dengan tujuan peserta mampu merancang pembelajaran berbasis $3 \mathrm{CM}$ learning sebagai solusi atas permasalahan yang dihadapi mitra.

d. Pertemuan keempat dilakukan melalui persentasi kelompok (SD, SMP dan SMA) dan revisi kelas daring yang telah dirancang oleh peserta dengan tujuan peserta mendapatkan masukan dari sudut pandang lain untuk menyempurnakan media yang telah dirancang.

e. Pertemuan kelima dilakukan melalui peerteaching dan ujicoba terbatas kelas daring oleh peserta dengan tujuan mengujicoba media 
pembelajaran yang telah dilakukan oleh peserta dan siap untuk diterapkan kepada siswa.

3. Evaluasi Pelaksanaan Program

Evaluasi ini dimaksudkan untuk mengetahui tanggapan dari peserta pendampingan pembelajaran daring inovatif berbasis 3CM learning dari pelaksanaan kegiatan pengabdian kepada masyarakat.

Kegiatan pengabdian ini didukung dengan teknologi berbasis Web dan LMS Moodle. Web yang dikembangkan untuk menyediakan fasilitas belajar untuk kelas daring parsial dan LMS moodle dikembangkan untuk memberikan fasilitas pembelajaran daring terpadu.

\section{HASIL DAN PEMBAHASAN}

Berdasarkan proses pengabdian masyarakat yang dilakukan, diketahui bahwa jumlah peserta yang mengikuti pengabdian masyarakat ini berjumlah 84 orang, dimana peserta berasal dari berbagai tingkatan baik SD, SMP maupun SMA. Instansi peserta berasal dari berbagai daerah di Indonesia dan sebagian besar adalah guru-guru dibawah LP3S.

Pengabdian masyarakat ini menunjukkan hasil penilaian terhadap model 3CM Learning dimana proses pengembangan kegiatan pembelajaran dapat diikuti dan dilakukan secara baik melalui pembelajaran daring/LMS 3CM Learning yang disediakan 3CM Center. Hal ini dapat dilihat dari hasil tanggapan peserta bahwa dengan adanya 3CM Center menyediakan bukan hanya sekedar fitur biasa yang ada pada platform lain, namun juga lebih kompreshensif. Hal ini dapat dilihat dalam pengembangan model memberikan peluang bagi peserta didik untuk belajar lebih menyenangkan dan menantang. Pada proses pembelajaran juga diberikan ruang untuk siswa mengembangkan kemampuan untuk memecahkan sebuah permasalahan yang ada di sekitar yang tentunya berhubungan dengan materi pembelajaran, mengembangkan kreativitas dalam menghasilkan sebuah produk yang bermakna sebagai hasil dari belajar yang dilakukan, serta memberikan ruang untuk mengembangkan sikap kritis dan karakter baik sebagai hasil refleksi dari pembelajaran.

Dengan adanya model 3CM Learning ini memberikan banyak pengetahuan tentang belajar daring, melatih pengajar untuk memberikan sesuatu yang menarik perhatian siswa dan meningkatkan kreatifitas siswa, menantang bagi pendidik maupun peserta didik dikarenakan hal ini merupakan hal yang baru jadi menjadi hal yang menarik untuk dicoba serta belajar dengan menggunakan model 3CM Learning sangat menarik untuk digunakan, karena baik guru maupun orang tua dapat meninjau aktivitas siswa dalam kegiatan pembelajaran apalagi pembelajaran yang dilaksanakan secara daring. Oleh karena itu, 3CM dapat memberikan kesan belajar yang menarik dan menyenangkan bagi siswa, juga dapat membantu guru atau pendidik dalam menyiapkan pembelajaran yang terstruktur dan terperinci. 

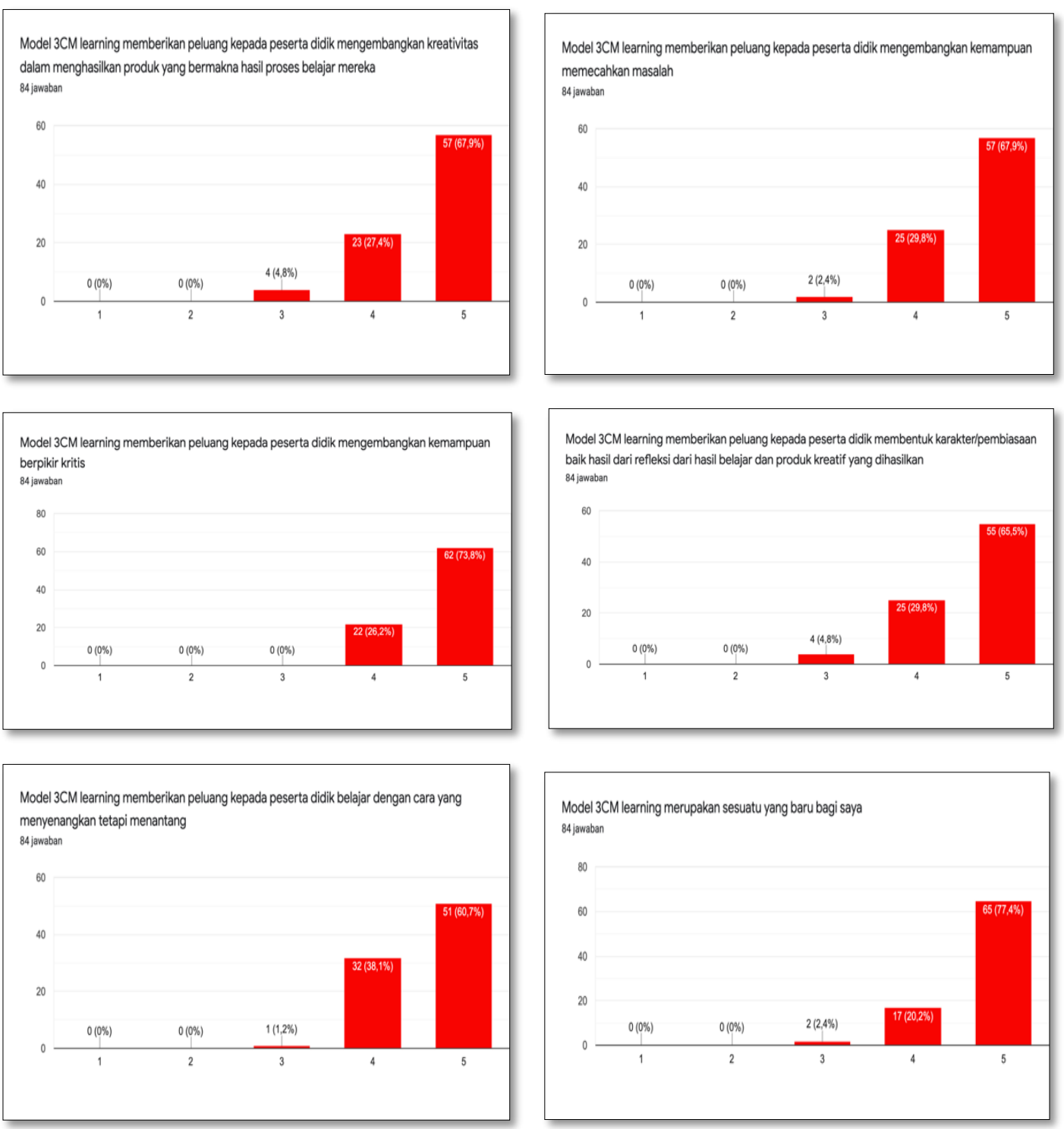

Gambar 4. Penilaian Terhadap Model 3CM Learning

Selain itu, Sistem dan Kelas Daring 3CM Center yang dapat diakses melalui $3 \mathrm{~cm}$-center.com dinilai sangat mudah untuk dipahami baik oleh guru yang menyiapkan media dan materi pembelajaran serta siswa sebagai peserta didik. Hal ini dapat dilihat dari tanggapan peserta bahwa system pembelajaran dari/LMS 3CM Learning mudah diikuti dan telah sesuai dengan prinsip 3CM Learning yang mengedepankan pembelajaran yang menantang, kritis, kreatif dan bermakna. Fiturfitur atau fasilitas yang disediakan dalam LMS 3CM dapat digunakan dan berfungsi dengan baik. Sistem 3CM mudah untuk dipahami dan menyajikan bukan hanya sekedar tulisan saja, namun bisa dikolaborasikan dengan gambar, audio dan bahkan video. Fitur lainnya, dalam sistem ini dianggap mempermudah guru dalam mengevaluasi hasil belajar siswa serta orang tua dapat melihat secara langsung bagaimana perkembangan belajar anak. Selain itu, anak tidak akan ketinggalan materi karena setiap materi yang disajikan harus diselesaikan satu persatu oleh siswa dan 
Pemdampingan Pembelajaran Daring Parsial dan Terpadu Berbasis 3CM (Cool-Critical-Creative-Meaningful) Learning untuk Mengatasi Kejenuhan Belajar dan Kreativitas Implikasi Dampak Covid-19 (Wahyudi, Tri Nova H. Yunianta, Erlina Prihatnani, Kristina Roseven Nababan, Dani Kusuma, Anisa Rizki Amalia, Bella Ayu Permatasari, Cindy Aprillya Sidarta, Bagas Prima Kristanto, Syera Trivena Dessiane, Erlin Prasetyo)

materinya selanjutnya akan otomatis terbuka. Hal ini yang menjadi nilai tambah yang patut untuk diapresiasi dalam sistem ini.
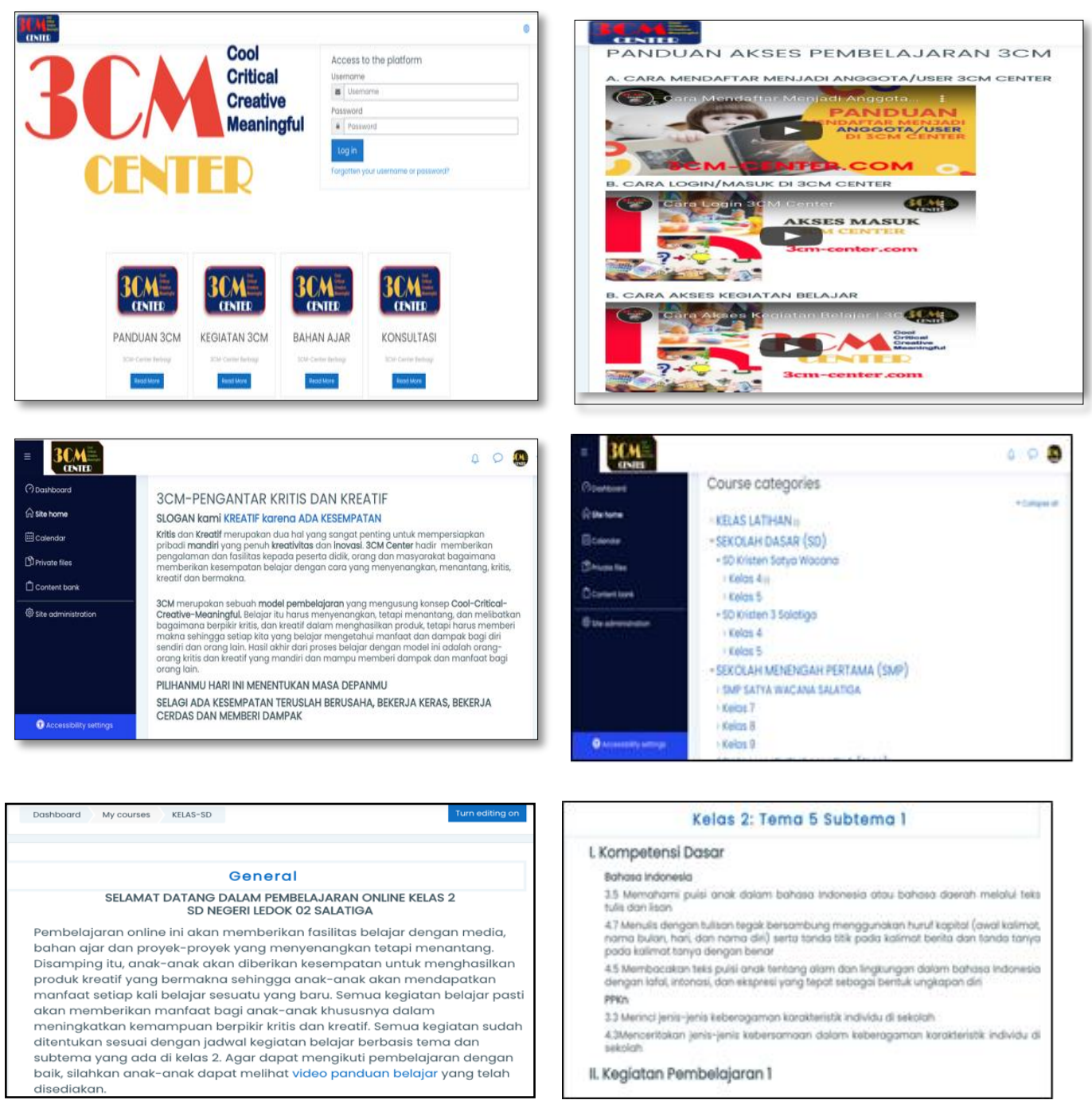

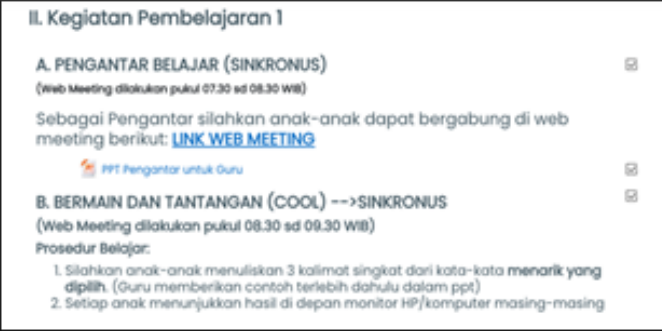

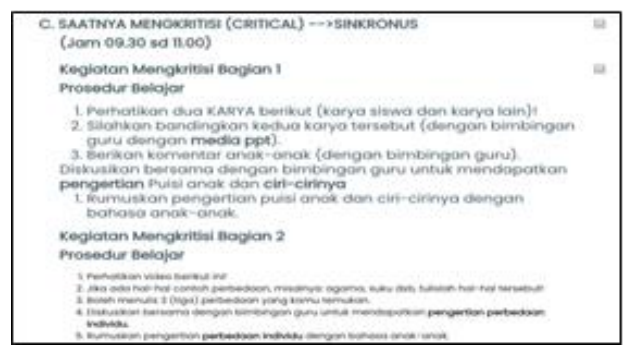



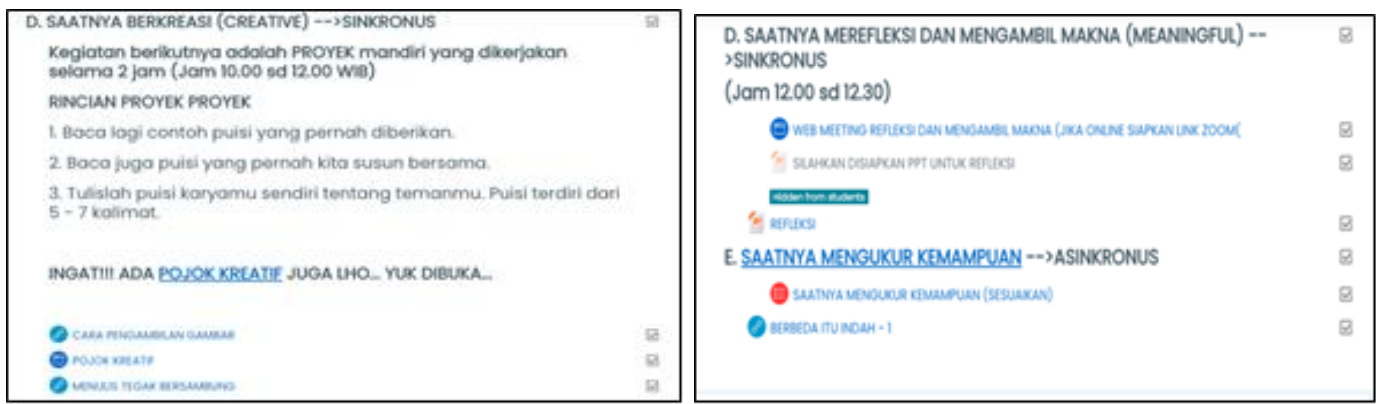

Gambar 5. Tampilan kelas terpadu 3CM Learning

Dengan adanya sistem dan kelas daring 3CM Center, semua materi dan penugasan siswa dapat dilihat dalam fitur 3CM. Kemudian, siswa juga dapat mengerjakan tugas-tugas dan dikumpulkan langsung di 3CM Center pula. Hal ini mempermudah siswa sekaligus mempermudah guru untuk mengoreksi tugas-tugas yang telah dikerjakan oleh siswa, serta penilaian juga akan transparan atau terbuka.
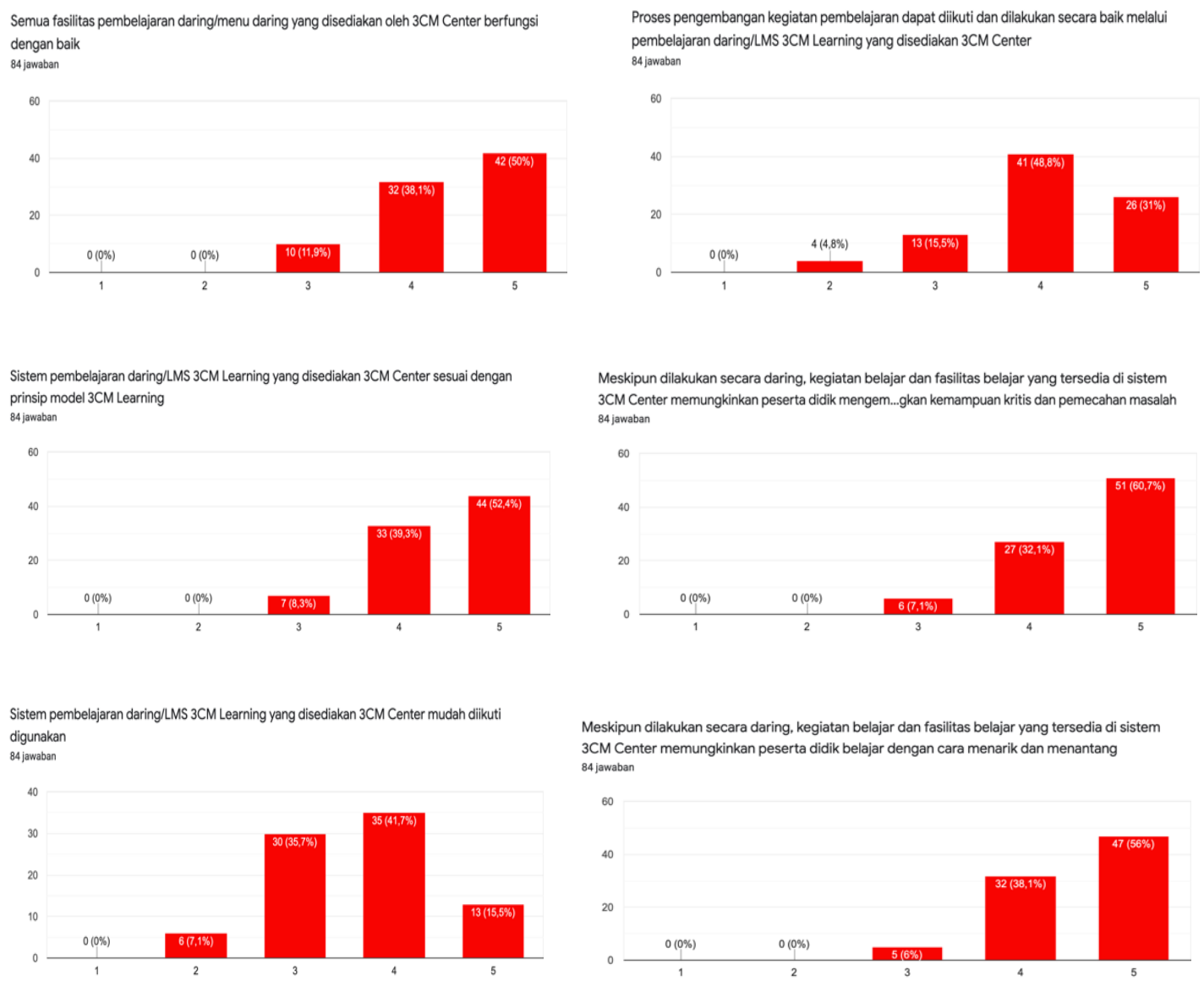

Gambar 6. Sistem dan Kelas Daring 3CM Center (3cm-center.com)

Proses pelatihan pendampingan pembelajaran daring parsial dan terpadu berbasis 3CM (cool-critical-creative-meaningful) learning dinilai sangat baik dan 
bermanfaat dalam pengembangan pembelajaran masa pandemi Covid-19 yang dianggap mampu mengatasi kejenuhan belajar dan kreativitas peserta didik. Kegiatan difasilitasi dan dipersiapkan dengan baik dimana agenda kegiatan disusun secara sistematis dan dapat dilaksanakan. Disamping itu, pemateri juga menyampaikan materi dengan baik dan menggunakan media yang mendukung dalam pelaksanaan pelatihan pendampingan yang akan dilakukan.
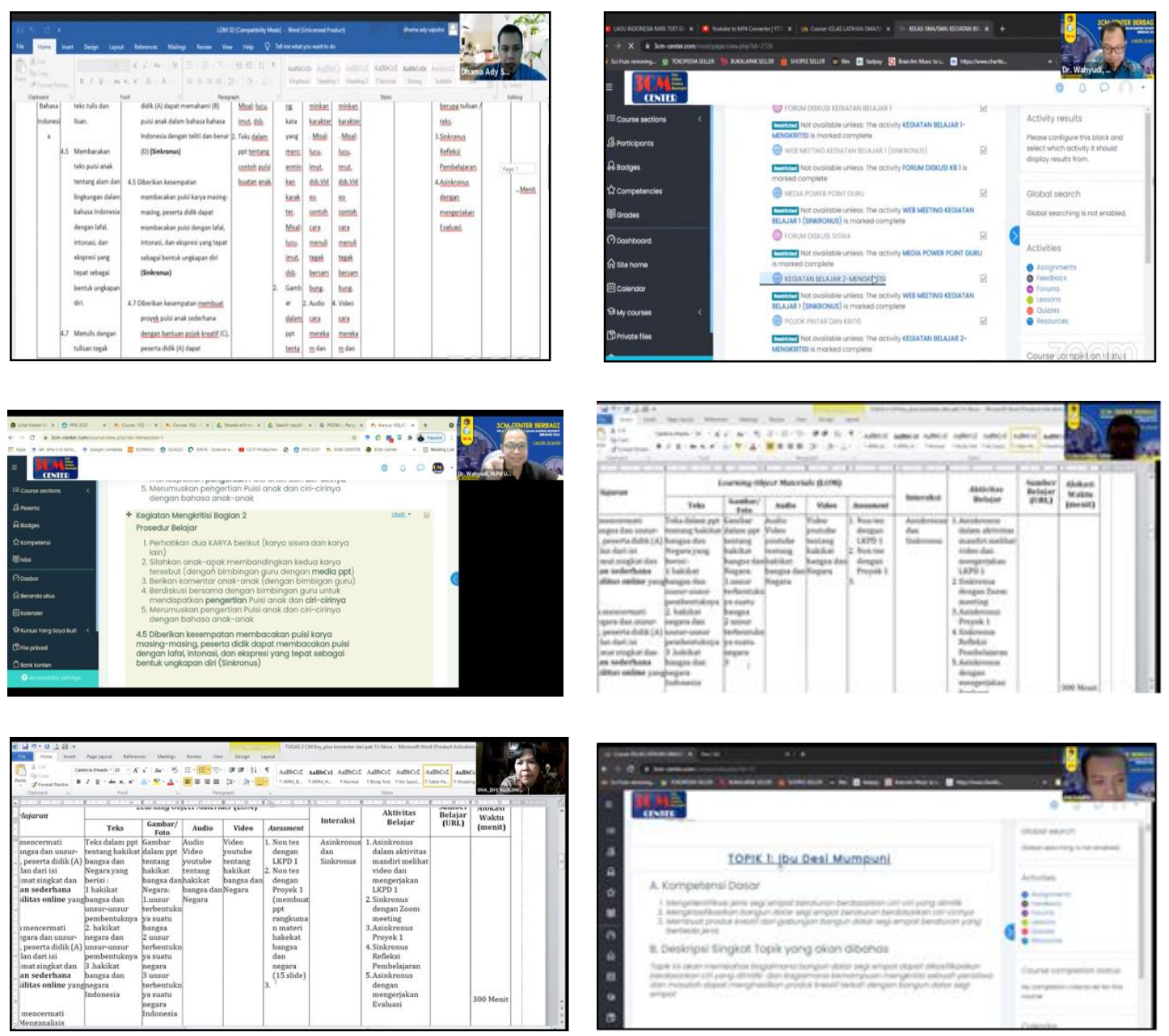

Gambar 7. Pendampingan Daring sesuai Jenjang

Pada saat pelaksanaan pendampingan, peserta menilai pelaksanaan sudah dilakukan dengan baik dimana peserta difasilitasi dalam pengisian materi dan media pembelajaran. Peserta juga didampingi dalam penentuan capaian pembelajaran yang meningkatkan minat peserta didik untuk belajar lebih menarik. 

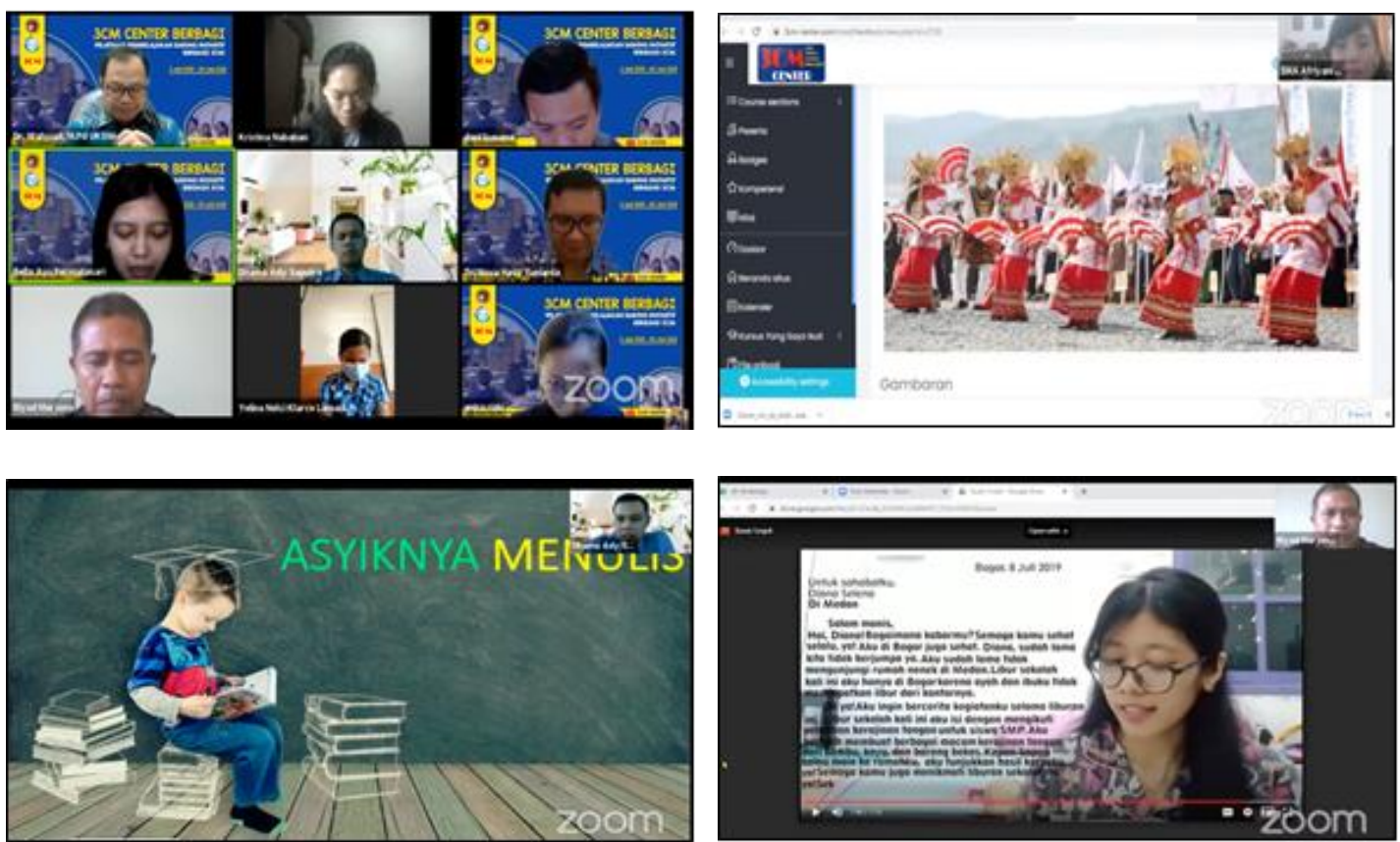

Gambar 8. Persentasi Hasil Rancangan Kelas Daring

\section{SIMPULAN}

Berdasarkan hasil dari pengabdian masyarakat ini dapat disimpulkan bahwa telah terjadi peningkatan pengetahuan dan keterampilan dari guru-guru dalam menyajikan materi dan menjawab permasalahan yang dihadapi pada masa pembelajaran di masa pandemi ini. Pemdampingan pembelajaran daring parsial dan terpadu berbasis $3 \mathrm{~cm}$ (cool-critical-creative-meaningful) learning ini juga dinilai mampu mengatasi kejenuhan belajar dan kreativitas siswa sebagai dampak Covid-19. Disarankan kepada sekolah maupun maupun instansi lain dapat menerapkan model 3CM Learning ini untuk meningkatkan pendidikan di masa pandemi Covid-19.

\section{DAFTAR PUSTAKA}

Dyer, J., Gregersen, H., \& Christensen, C. M. (2011). The innovator's DNA: Mastering the five skills of disruptive innovators. Harvard Business Press.

Kadir, Lucyana, Satriawati, \& Gusni. (2016). The Implementation Of Open-Inquiry Approach To Improve Students' Learning Activities, Responses, And Mathematical Creative Thinking Skills. Journal on Mathematics Education, 8(1), 103-114. https://doi.org/10.22342/jme.8.1.3406.103-114

Leikin, R. (2013). Evaluating mathematical creativity: The interplay between multiplicity and insight1. Psychological Test and Assessment Modeling, 55(4), 385.

Mann, E. L. (2006). Mathematical creativity and school mathematics: Indicators of mathematical creativity in middle school students 1956. Dissertation Abstracts International Section A: Humanities and Social Sciences, 67, 461.

Undang-Undang Nomor 20 Tahun 2003 Tentang Sistem Pendidikan Nasional, Depdiknas (2003). https://doi.org/10.1111/j.1651-2227.1982.tb08455.x

Navarrete, C. C. (2013). Creative thinking in digital game design and development: A case study. Computers \& Education, 69, 320-331. 
https://doi.org/10.1016/j.compedu.2013.07.025

Nuha, M. 'Azmi, Waluya, S. B., Junaedi, \& Iwan. (2018). Mathematical Creative Process Wallas Model in Students Problem Solving with Lesson Study Approach. International Journal of Instruction, 11(2), 527-538.

Sternberg, R. J. (2006). The Nature of Creativity. Creativity Research Journal, 18(1), $87-98$.

Sternberg, R. J. (2012). The Assessment of Creativity: An Investment-Based Approach. Creativity Research Journal, 24(1), 3-12. https://doi.org/10.1080/10400419.2012.652925

Tindowen, D. J. C., Bassig, J. M., \& Cagurangan, J.-A. (2017). Twenty-First-Century Skills of Alternative Learning System Learners. SAGE Open, 7(3), 1-8. https://doi.org/10.1177/2158244017726116

Vale, I., \& Barbosa, A. (2015). Mathematics Creativity in Elementary Teacher Training. Journal of the European Teacher Education Network, 10, 101-109. 